\title{
Are first year students ready for a flipped classroom? A case for a flipped learning continuum
}

\author{
Louisa Tomas ${ }^{1 *}$ (D) Neus (Snowy) Evans ${ }^{2}$, Tanya Doyle ${ }^{1}$ and Keith Skamp ${ }^{3}$
}

\author{
* Correspondence: \\ Louisa.Tomas@jcu.edu.au \\ ${ }^{1}$ College of Arts, Society \& \\ Education, James Cook University, 1 \\ James Cook University Drive, \\ Townsville, QLD 4811, Australia \\ Full list of author information is \\ available at the end of the article
}

\begin{abstract}
In our first year science and sustainability education subject, how to best support pre-service teachers to meet the conceptual demands of understanding important socio-ecological challenges such as climate change is a key focus of our teaching practice. In this multi-method case study, we explore how a flipped classroom supported students' engagement and learning by way of an end-of-semester student survey, and a narrative account of our experiences, as educators, enacting the active learning strategies in class. Analysis of survey data showed that while students reported a high level of engagement with the videos and believed that they supported their learning, opinions were divided as to whether a flipped classroom was preferred over traditional lectures. Additionally, our reflections on how students engaged with the active learning strategies revealed that significant time was required at the start of class to review key concepts, as students appeared reluctant to engage independently with the planned activities-particularly those that involved more challenging science concepts. Informed by these findings, we propose a flipped learning continuum that fosters different levels of student-centred learning and autonomy, depending on students' learning needs and their readiness for a flipped learning approach. In the context of the first year experience, specifically, some teacher-led instruction may be appropriate in a flipped classroom to support students' transition to learning in higher education.
\end{abstract}

Keywords: Flipped learning, Higher education, First year experience, Science education, Sustainability education, Pre-service teacher education

\section{Introduction}

Increasingly, universities are being charged with producing a new kind of graduate creative, critical thinkers able to synthesise and respond to complex socio-ecological problems (Cortese, 2003; Wals \& Jickling, 2002). At the same time, universities are under pressure to innovate their learning and teaching, while supporting an increasingly diverse student cohort's transition into higher education (Crosling, Heagney, \& Thomas, 2009). These mandates call for critical and reflexive approaches to teaching and learning.

Blended learning approaches "strategically, systematically and effectively integrate a range of technology enhanced learning across physical and virtual environments" (James Cook University, 2014, section 3). In this way, they are "partially virtual,

(c) The Author(s). 2019 Open Access This article is distributed under the terms of the Creative Commons Attribution 4.0 International License (http://creativecommons.org/licenses/by/4.0/), which permits unrestricted use, distribution, and reproduction in any medium, provided you give appropriate credit to the original author(s) and the source, provide a link to the Creative Commons license, and indicate if changes were made. 
partially tangible" (Glazer, 2012, p. 1). Such approaches have been shown to offer a range of affordances, such as enhancing and extending student learning (Osguthorpe \& Graham, 2003; Singh, 2010). In the context of an increasingly diverse student cohort, blended learning can enhance educational access and lead to improved student success for both minority and non-minority students (Dziuban, Graham, Moskal, Norberg, \& Sicilia, 2018). Blended learning approaches also tend to be received favourably by students as they offer flexibility and choice over when and how they learn, with access to different modes of study, and a range of multimodal learning resources (Keppell \& Riddle, 2011).

The flipped (or inverted) classroom is a blended learning approach that reverses the traditional university teaching and learning model (O'Flaherty \& Phillips, 2015). When learning is flipped, didactic lectures, which usually take place during face-to-face time, are pre-recorded and made available for students to watch prior to class, while opportunities to deepen, extend and apply student understanding of the recorded material are afforded by way of 'active learning strategies' in class time (Cheng \& Weng, 2017; Roehl, Reddy, \& Shannon, 2013; Zainuddin \& Halili, 2016). Active learning strategies are student-centred instructional activities that requires students to 'do things' and think about and reflect on what they are doing (Bonwell \& Eison, 1991; Misseyanni, Lytras, Papadopoulou, \& Marouli, 2018). A number of student-centred learning theories and methods used to guide the design of in-class activities include peer-assisted learning, cooperative learning, problem-based learning, collaborative learning and peer tutoring (Bishop \& Verleger, 2013). In this way, flipped learning "represents a unique combination of learning theories once thought to be incompatible-active, problem-based learning activities founded upon a constructivist ideology and instructional lectures derived from direct instruction methods founded upon behaviorist principles" (Bishop \& Verleger, p. 1).

In this paper, we investigate the implementation of a flipped approach to teaching and learning in a science and sustainability education subject (or 'course'), Foundations of Sustainability in Education (FSE), undertaken by all first year pre-service teachers in the Bachelor of Education (Early Childhood Education and Primary) at James Cook University (JCU). This study was conducted on two of the University's major regional campuses.

Through their engagement with FSE, students explore a number of socio-ecological challenges, such as climate change, biodiversity conservation and food security, through a series of six modules, with consideration of classroom pedagogy for science and sustainability education. The subject's learning outcomes prioritise the development of evidence-informed values and positions relating to sustainability, as well as the development of students' scientific literacy. While an understanding of Earth's systems is essential if students are to engage critically with the complex sustainability issues explored in the subject (Morse, 2000), researchers also consistently find that elementary teachers lack the science content knowledge needed to teach science effectively (Roth, 2014). For these reasons, the subject matter in FSE includes a strong focus on the underpinning science concepts.

A blended learning approach has been adopted in FSE that is centred around a shared platform in the university's online learning management system (LMS). Opportunities to achieve the subject's learning outcomes are provided through carefully designed learning experiences and interactions with teaching staff, supported by 
learning technologies. Within this approach, weekly, two-hour mass lectures facilitate teacher-led delivery and explanation of learning material, with the inclusion of short online videos, revision and summary exercises, science demonstrations and case studies. One-hour tutorials conducted with groups of approximately 25 students provide opportunities for experiential learning and consideration of classroom pedagogies for science and sustainability education. A detailed description of the curriculum, pedagogies and assessment employed in FSE can be found in Tomas, Lasen, Field and Skamp (2015), and Lasen et al. (2015).

Students who complete FSE report very high levels of satisfaction with the subject via the University's teaching evaluation survey. Nonetheless, student feedback and our own observations suggest that learning new science and sustainability concepts is very difficult for many students, particularly as some have received a limited school science education, and most have no prior experience in sustainability education (Australian Education for Sustainability Alliance, 2014; Evans, Tomas, \& Woods, 2016). At the same time, students are adjusting to university life and expectations in the first year of their degree.

With a view to support our first year students' engagement, learning and success, we considered a flipped learning approach that focuses on some of the more challenging science and sustainability concepts taught in the subject most suitable for enhancing the blended learning design already adopted in FSE. The aim of this study was to investigate how this approach supported first year students' engagement and learning, by eliciting students' perceptions of their experience in the subject, and educators' perspectives on enacting the active learning strategies 'in class' (i.e., the allocated mass lecture time). While previous research into flipped learning has privileged the student voice, far fewer studies have focused on educators' experiences (see Bishop \& Verleger, 2013), or drawn on narrative inquiry as a way of illuminating these experiences, as is done in this study. At the time this research was conducted, the authors were aware of only two studies that employed narrative to explore educators' experiences implementing a flipped classroom in a secondary school (Huereca, 2015) and higher education setting (Howitt \& Pegrum, 2015). The current study is also significant because an important outcome was the development of a 'flipped learning continuum, which offers a way of adapting the usual flipped learning model in a way that is responsive to students' learning needs and their 'readiness' for a flipped approach. We begin by reviewing the literature regarding the affordances of a flipped classroom in higher education, before describing the flipped learning approach enacted in FSE, and the research questions that guided our study.

\section{Flipped learning in higher education}

A key premise of flipped learning is that students engage with important content in advance of attending class, while opportunities for higher order thinking are afforded during class time (O'Flaherty \& Phillips, 2015). In their comprehensive review of existing research into flipped learning in higher education, Bishop and Verleger (2013) reject broad definitions of flipped learning that suggest assigning readings prior to class and engaging in group discussions during class time constitutes a flipped learning approach. They define a 'flipped classroom' as one that employs "interactive group learning activities inside the classroom, and direct computer-based individual instruction [i.e., video lectures] outside the classroom" (p. 5). This is the definition of flipped learning adopted in FSE. 
A growing body of research has found that flipped learning can offer a number of advantages for both teachers and students. For example, using active learning strategies in class enables teachers to understand better students' learning styles and difficulties; to use class time more effectively and creatively; and to meet the learning needs of diverse student cohorts by customising the curriculum and offering personalised teacherto-student mentoring and peer-to-peer collaboration (Fulton, 2012; Roehl et al., 2013). Students also respond positively to flipped learning approaches, with studies reporting that such approaches are more effective at engaging students than traditional university lectures (Fulton, 2012; McCarthy, 2016; Nouri, 2016), and eliciting positive emotions and attitudes toward learning (Jeong, González-Gómez, \& Cañada-Cañada, 2016). Roehl et al. (2013) and Vaughan (2014) contend that, in the age of Millennial learners, engagement is a more important consideration than ever, arguing that Millennials are more intolerant than other generations to traditional lecture-style pedagogies.

The potential benefits of a flipped classroom are tempered by two main concerns that (a) considerable work is required to create and coordinate learning materials and activities, particularly quality flipped videos, and (b) students may be resistant to doing the required work at home and come unprepared to class to participate in planned activities (Herreid \& Schiller, 2013; Milman, 2012). It has also been suggested that posting videos online may not offer sufficient scaffolding for some students, as they are unable to ask questions to clarify their ideas in real time, and similarly, teachers cannot pose questions to check for understanding as learning is taking place (Howitt \& Pegrum, 2015). Additionally, it is to be noted that while there have been reported learning gains arising from flipped approaches in a range of disciplines (e.g., Baepler, Walker, \& Driessen, 2014; Jensen, Holt, Sowards, Ogden, \& West, 2018; Love, Hodge, Grandgenett, \& Swift, 2014), the impact of such approaches on student learning outcomes remains under-researched (see Lundin, Rensfeldt, Hillman, Lantz-Andersson, \& Peterson, 2018).

\section{The flipped learning approach in FSE}

The fields of science and sustainability education espouse active and participatory pedagogical approaches as a means of optimising student engagement and higher order thinking. In this context, effective teaching for learning requires students to engage in critical thinking to address complex issues such as climate change and our energy future (Wals, Brody, Dillon, \& Stevenson, 2014). Scholars argue that responding to such multifarious problems requires student-centred approaches that develop learners' capacity to think critically and creatively (Stevenson, Brody, Dillon, \& Wals, 2013). At the forefront of such approaches are inquiry-based pedagogies that engage students in learning through, for example, stimulus and problem-based activities, group discussions, case studies and fieldwork (Cotton \& Winter, 2010; Nichols, Burgh, \& Kennedy, 2017). The underlying themes of such science and sustainability pedagogies strongly align with more student-centred, constructivist philosophies of learning, rather than didactic lecture-style pedagogies. For us, the clear philosophical and practical synergies between flipped learning, and science and sustainability education, presented a promising approach for engaging and supporting students in FSE.

Our experience teaching FSE tells us that students find particular sustainability issues and concepts more difficult to learn than others; particularly those that are complex and implicate multiple factors, and require a strong grasp of underpinning science 
concepts (see also, Warburton, 2003). FSE is delivered in a 13-week semester, wherein the first week presents an introduction to the subject and Education for Sustainability, while the final week focuses on preparation for an end-of-semester examination that tests students' understanding of key concepts. Of the 11 weeks that remain, we identified seven that students find difficult (as supported by previous achievement in the subject's assessment). As there is no evidence in the literature that flipping only selected class sessions or modules is any less beneficial than flipping an entire course (see O'Flaherty \& Phillips, 2015), we chose these weeks to be the focus of our flipped learning approach, that was implemented for the first time in 2014.

For these weeks, a suite of short (5-10 min) 'flipped videos' was developed using Camtasia $^{\text {tw }}$ (a screen-based video capture and editing software), and embedded in the online modules on the LMS at least a week prior to them being used. The videos comprised of either the first or second author narrating a PowerPoint ${ }^{\mathrm{Tw}}$ presentation (with a talking head) that explicitly teaches key, foundational science and sustainability concepts. Each video begins with an outline of the presentation and why the concept/s are important to students' understanding of sustainability. The videos go on to teach the focus concepts in a simple, step-by-step manner, with supporting text, diagrams and illustrations. Finally, they conclude with a summary of the main points, followed by two or three short review questions for students to answer, as a self-check tool. Videos were developed for the topics of human population growth, water chemistry (two videos: Part 1 and Part 2, shown over 2 weeks), energy, biodiversity, stratospheric ozone depletion, and the enhanced greenhouse effect. An additional introductory video was developed that explicated the rationale for adopting a flipped classroom; compared the characteristics of a traditional lecture and flipped classroom; and outlined our expectations for engaging with this approach.

Each week in FSE, students are required to work through the online module materials; download and read a copy of the lecture notes provided on the LMS; and complete the required readings. For the seven flipped weeks, students were also required to watch the flipped videos carefully and answer the review questions in preparation for class. It was suggested that they take their own notes, write down questions, and annotate the accompanying PowerPoint ${ }^{\mathrm{tm}}$ presentation (which was provided online).

For each of the 'flipped lectures', the content covered in the corresponding flipped video/s was replaced with a student-centred activity that requires students to recall and apply, and in some cases, extend the knowledge that they learnt before class. These activities (a sample of which is summarised in Table 1) are facilitated by the lecturer, and generally occupy $45 \mathrm{~min}$ to $1 \mathrm{~h}$ of the 2-h 'lecture'. During the activities, the lecturer can move between groups of students to answer questions. At the end of each activity, the work or artefacts produced by students are shared, reviewed and discussed, before moving on with the remainder of the lecture. Any content or learning activities that are not covered by the flipped videos are delivered as normal, and all of the weekly tutorials in FSE remained unchanged.

\section{Research questions}

In investigating how a flipped learning approach supported students' engagement and learning in FSE, two particular aspects were focused upon. First, we were interested in identifying our students' perceptions of the flipped learning approach, given that they 
Table 1 A summary of two flipped learning weeks in FSE. The left-hand column outlines the topic and key concepts explored in the flipped videos, while the right-hand column presents a summary of the active learning strategies implemented in class

\begin{tabular}{|c|c|}
\hline Flipped video topic and key concepts & Active learning strategy \\
\hline $\begin{array}{l}\text { Week 2: An introduction to human population } \\
\text { growth. }\end{array}$ & $\begin{array}{l}\text { - In small groups, students construct a mind map that illustrates } \\
\text { the key ideas associated with current trends in human } \\
\text { population and the contributing factors. }\end{array}$ \\
\hline $\begin{array}{l}\text { Current trends in human population } \\
\text { growth and the reasons behind them. }\end{array}$ & $\begin{array}{l}\text { - In doing so, students consider the following questions: How is } \\
\text { the world's population trending? Why? Drawing on Reading } 1 \\
\text { (Campbell, 2007), what are the implications for fertility and } \\
\text { child mortality? Compare developing versus developed regions. }\end{array}$ \\
\hline $\begin{array}{l}\text { Week 11: An introduction to the greenhouse } \\
\text { effect. }\end{array}$ & $\begin{array}{l}\text { - In pairs, students draw a labeled diagram that illustrates the } \\
\text { greenhouse effect, and compare, discuss and refine diagrams } \\
\text { with a neighbouring pair. }\end{array}$ \\
\hline $\begin{array}{l}\text { What is the greenhouse effect, and how it } \\
\text { occurs. }\end{array}$ & $\begin{array}{l}\text { - Students complete the What I know and What I want to know } \\
\text { section of the KWL chart (handout) and return it to their lecturer. }\end{array}$ \\
\hline
\end{tabular}

are required to take greater responsibility for their learning than is required in traditional lectures. As well as investigating students' broader perceptions of a flipped classroom, we explored specifically how students engaged with the videos in their own time, given their importance to students' preparedness for class. Second, we sought to describe and reflect on our experience, as educators, of enacting the active learning strategies during class. We chose this focus given that a flipped learning approach calls for a notable shift in the educator's role during class time, from that of instructor to a facilitator of active learning (Chen, Wang, Kinshuk, \& Chen, 2014). Such a focus is also warranted, given that existing studies of flipped classrooms tend to privilege students' perceptions, and yet, educators play a critical role in enacting flipped learning approaches successfully (Chen et al., 2014; Howitt \& Pegrum, 2015).

With these foci in mind, the following four research questions informed the research design:

1. How do students engage with the flipped videos in FSE?

2. In what ways do students report that the flipped videos support their learning of key concepts in FSE?

3. What are students' perceptions of the flipped learning approach in FSE?

4. What are educators' perspectives on enacting the active learning strategies during class time?

\section{Research methods}

In this multi-method case study (Yin, 2018), a survey generated quantitative and qualitative data regarding students' experiences and perceptions of the flipped learning approach (and particularly of the flipped videos), while teaching observations and self-reflections drawn from a journal completed by the first and second authors (Louisa and Neus [Snowy] respectively) captured our perspectives on enacting the active learning strategies with a view to understand better how students engaged with the planned activities. In this pragmatic approach, complimentary sources of data were used to develop a deeper understanding of the research problem (Morse, 2003). Each data source and our approach to analysis are outlined below. 


\section{Data collection and analysis}

In seeking answers to Research Questions 1-3, we elicited students' views on their experiences of teaching and learning in FSE by way of a survey that was administered to consenting students who studied the subject in 2014 and 2015. The instrument was developed specifically for the purposes of our research. It comprises six questions that generate data through dichotomous questions, a Likert-scale, and open-ended, free-response questions (Fig. 1). The instrument was delivered online and was made available to students via the LMS, and was also offered to students to complete on paper at the last lecture, with a view to enhance the response rate (Nulty, 2008). Students were invited to complete the survey once at the end of the teaching semester, before the final examination. It took 10-15 min to complete and was done so anonymously. The survey was administered to two cohorts of students; the 2014 cohort who experienced the first (pilot) delivery of the flipped learning approach, and the 2015 cohort who experienced the second flipped learning delivery. We made the decision to administer the survey again in the second year after reflecting on our experiences of the pilot year. This enabled us to draw on our reflections and refine our practice during the subsequent year's delivery.

In total, 171 students completed the survey (noting that approximately 240 students complete FSE in any given year): 114 in 2014 (a 46\% response rate), and 49 in 2015 (a 26\% response rate). While the survey was promoted equally in both years, a much lower response rate was secured in 2015. Nonetheless, these response rates are more than adequate in the context of the given class size to draw useful conclusions about how our flipped learning approach supported students' engagement and learning (Nulty, 2008). No direct comparisons between the data for the 2 years were made.

1. Please indicate which, if any, of the following seven flipped videos you watched in FSE and estimate the number of times you watched each one.

2. I will be revisiting the videos in preparation for the final exam: $\square$ YES $\square$ NO

Please answer the following questions if you watched any of the flipped videos in FSE - as shown in Question 1. Thinking back to the videos that you watched:

3. When did you usually watch the videos? $\square$ Before lectures $\square$ During lectures $\square$ After lectures

4. Do you feel the videos helped you to understand the module content? $\square$ YES $\square$ NO

a. If Yes: In what way were the videos most helpful to your learning?

b. If No: Why were they not helpful?

5. In what ways, if any, could the videos be improved?

If you didn't watch some or all of the videos - as shown in Question 1:

6. Why didn't you watch them?

7. What would have encouraged you to watch the videos?

8. Finally, rate each item to indicate your agreement (Strongly agree, agree, neither agree nor disagree, disagree, strongly disagree):

- The flipped classroom approach made me feel more motivated to learn the content within this module.

- I found the flipped classroom more engaging than traditional classroom instruction.

- I would not recommend the flipped classroom approach.

- I would rather a traditional classroom approach than the flipped classroom approach.

Fig. 1 A summary of the survey instrument employed in this study 
Students' responses to the survey's dichotomous questions and Likert scale (Questions 1-4 and Question 6) were analysed quantitatively using descriptive statistics. Responses to Question 6 were scored on a scale of 1 to 5 , such that 1 corresponded to 'Strongly agree', while 5 corresponded to 'Strongly disagree'. Students' free responses to Questions 4 and 5 were analysed manually using an inductive approach (Saldaña, 2013). Participants' responses were exported to a spreadsheet and read in their entirety a number of times to identify emergent themes. As analysis progressed, these themes were coded and revised in an iterative process, guided by the aim of our study. The coding for this part of the analysis was discussed and refined by the first and second authors until they were in agreement.

In answering Research Question 4, a 'narrative account' of Louisa and Snowy's experiences enacting the active learning strategies was written, as both educators were responsible for developing and implementing the flipped approach for the first time in 2014. Narratives are being used increasingly in educational research as a way of coming to understand participants' lived experiences (Clandinin \& Connelly, 2000). Narrative inquiry is particularly suited in this context, given that "education [can be viewed] as the construction and reconstruction of personal and social stories" (Connelly \& Clandinin, 1990, p. 2). Narrative has also been used in a recent case study by Howitt and Pegrum (2015) to describe their experiences implementing a flipped learning approach in postgraduate education courses at an Australian university.

In developing a narrative account, Louisa and Snowy engaged collaboratively in reflective analysis of their recorded teaching observations and self-reflections (see Connelly \& Clandinin, 1990). In reflective analysis, researchers draw upon their intuition and judgement in coming to understand the phenomena under study; a subjective approach that is suited to case study research (Gall, Borg, \& Gall, 2007). In 2014, Louisa and Snowy were each responsible for implementing the flipped learning approach on one of JCU's campuses. Over the course of the semester, they individually recorded their experiences of enacting the active learning strategies, with a focus on how students engaged with and responded to the activities. As a collaborative teaching partnership, they would talk regularly before class to discuss their approach to teaching and learning, and afterwards to debrief by sharing their observations and reflections. These discussions helped to inform their teaching in the following week. At the end of the semester, the data was examined and re-examined until common themes emerged (cf. Howitt \& Pegrum, 2015). Although Louisa and Snowy each taught FSE on two different university campuses, they found much common ground in their experiences to enable the telling of a single, unified narrative. The narrative was discussed and refined until they were satisfied that it represented an authentic account of their perspectives, as educators, of enacting the active learning strategies in FSE.

To ensure the trustworthiness of the narrative account and the interpretations arising from the reflective analysis, two criteria were addressed: verisimilitude and utility (Connelly \& Clandinin, 1990; Loh, 2013). According to Loh (2013), these criteria are essential to ensure the trustworthiness of "the participant's particularized meaningmaking interpretations" (p. 9) in narrative inquiry. Verisimilitude concerns whether the narrative is plausible and "... aids in the understanding of the subjective world of the participants", while utility refers to whether the narrative inquiry is useful, or relevant, to the intended readers and users of the research (Loh, 2013, p. 10). Both 
verisimilitude and utility can be established by engaging in peer validation, a form of member checking whereby scholars who are familiar with the field of research, and who have conducted research within the field themselves, "... provide some sort of corroboration with regard to the interpretation of the data" (Loh, p. 6). In seeking peer validation, the narrative account and the interpretations arising from the reflective analysis were sent to an experienced teacher educator at another Australian university with extensive experience teaching, researching and writing in the fields of primary education; science and sustainability education; and blended learning ${ }^{1}$. He was asked to provide his views on whether the narrative account and subsequent interpretations were plausible, reasonable and offered utility to other university educators seeking to develop and implement a flipped learning approach.

In his written validation (Appendix), the verisimilitude of the narrative account was established, as the observations of how students engaged with the active learning strategies in class were deemed "highly plausible" given they resonated with his own experiences teaching science education to first year undergraduate students. The subsequent interpretation of the narrative account was considered appropriate and insightful (as supported by relevant literature), as he could "identify with the proffered interpretations". Finally, the utility of the narrative account was affirmed as it illuminates "... what might eventuate if [other university educators] decide to use ... a flipped learning approach in their units/courses. If they experience difficulties, then the conclusions from the narrative (and the linked survey findings) could prove to be most useful as they would then be able to identify with these teacher educators' experiences and explore their suggestions for ways forward" (K. Skamp, personal communication, July 24, 2018).

\section{Findings}

In the four subsections that follow, the outcomes of our analyses are presented, aligned to each of the research questions. In doing so, we outline five key findings that illuminate how the flipped learning approach in FSE supported students' engagement and learning.

\section{Students' engagement with the flipped videos}

\section{Key finding 1: the majority of students watched the flipped videos more than once, generally prior to attending class}

The survey findings paint an encouraging picture of students' engagement with the flipped videos (Table 2). While no single respondent indicated that he/she watched all of the videos, less than $6 \%$ indicated that they watched no videos at all. The average number of views per video ranged from 2.1 to 2.5 views over the semester. A greater proportion of students watched the videos more than once for Week 3 and Week 10, which could be attributed to the more challenging nature of the scientific concepts explored. Most students $(97 \%, n=160)$ indicated that they would revisit the videos in preparation for the examination.

The majority of respondents $(\sim 80 \%)$ viewed the flipped videos before class, while nearly $40 \%$ watched the videos after class (see Table 3 ). Given that students could select more than one response to this question (and that the average number of views per video was > 2.0), it is likely that a number of respondents viewed the videos at different 
Table 2 A summary of the flipped videos viewed by survey respondents during the semester, and the number of times they were viewed $(n=171)$

\begin{tabular}{|c|c|c|c|c|c|c|c|}
\hline \multirow[t]{2}{*}{ Flipped videos } & \multirow{2}{*}{$\begin{array}{l}\text { Viewed by } \\
\text { n (\%) } \\
\text { respondents }\end{array}$} & \multicolumn{5}{|c|}{$\begin{array}{l}\text { Number of times respondents } \\
\text { viewed the videos }(n)\end{array}$} & \multirow{2}{*}{$\begin{array}{l}\text { Mean } \\
\text { views } \\
\text { (n) }\end{array}$} \\
\hline & & 0 & 1 & 2 & 3 & $\geq 4$ & \\
\hline Week 1: Introduction to flipped learning in FSE & $163(95.3)$ & 25 & 118 & 15 & 1 & 4 & 2.1 \\
\hline Week 2: Human population growth & $160(93.6)$ & 25 & 105 & 25 & 0 & 5 & 2.2 \\
\hline Week 3: The physical and chemical properties of water I & $158(92.4)$ & 21 & 83 & 41 & 8 & 5 & 2.5 \\
\hline Week 3: The physical and chemical properties of water II & $159(93.0)$ & 33 & 71 & 42 & 6 & 7 & 2.4 \\
\hline Week 6: Energy & $158(92.4)$ & 30 & 92 & 26 & 6 & 4 & 2.2 \\
\hline Week 10: Stratospheric ozone depletion & $153(89.5)$ & 25 & 78 & 40 & 2 & 8 & 2.4 \\
\hline Week 11: Global climate change & $151(88.3)$ & 30 & 93 & 21 & 1 & 6 & 2.2 \\
\hline I did not watch any of the videos. & $10(5.8)$ & & & & & & \\
\hline
\end{tabular}

times (e.g., before and after the lecture). Eighteen students (11.2\%) indicated that they watched the videos at other times, including during the lectures. Twelve students offered explanations as to when they viewed the videos. The need to accommodate multiple commitments was frequently cited (e.g., "Whenever I had a chance between fulltime work and other subjects", and "Depending on time, I would aim to watch before, but some I had to watch after lectures"). Two students explained that when they viewed the videos depended on their content, which suggests that they may have elected to watch particular videos in response to their individual learning needs.

\section{Key finding 2: a perceived lack of time was why a significant minority of students did not} watch one or more of the flipped videos before the class

Seventy students $(41 \%)$ offered explanations to account for why they did not watch some or all of the flipped videos (Table 4). Nearly half of respondents $(n=32)$ indicated that they did not have enough time to watch them. As one student candidly explained, "I'm sure they were all very helpful but I lacked the time and motivation, they were not a priority". Nine students reported that study and assessment commitments for other subjects meant that they did not have enough time to watch them. The demands of juggling study commitments were also made evident by another student who explained, "I ran out of time some weeks with trying to keep on top of all of my subjects". Another important reason as to why students neglected to watch the flipped videos was that they simply forgot to do so $(n=22)$ : "I would usually forget, but [I] will be watching them all before exam".

Table 3 A summary of when students viewed the flipped videos $(n=161)$

\begin{tabular}{lc}
\hline Response options & Responses $n(\%)$ \\
\hline Before lectures & $128(79.5)$ \\
During lectures & $6(3.7)$ \\
After lectures & $64(39.8)$ \\
Other & $12(7.5)$ \\
\hline
\end{tabular}

Note: Students could select more than one response to this question 
Table 4 A summary of students' reasons why they didn't watch the flipped videos

\begin{tabular}{lc}
\hline Reason & Frequency \\
\hline Lack of time & 32 \\
Forgot & 22 \\
Did not need to watch them & 5 \\
Problem with Internet access or technical issues & 5 \\
Lack of personal motivation or interest & 4 \\
Read the flipped video notes instead & 2 \\
Lack of personal organisation & 2 \\
\hline
\end{tabular}

\section{Students' reports of the ways in which the flipped videos supported their learning}

\section{Key finding 3: the flipped videos were reported to provide virtually all students with requisite knowledge that helped them to either prepare more effectively for class, or to} better understand the lectures

The survey revealed that $98.8 \%$ of students who responded to Question 4 believed that viewing the flipped videos helped them to understand the key concepts in FSE. From the 159 responses related to ways in which the flipped videos were helpful for their learning (a summary of which is presented in Table 5), the main reasons were (extracts from student responses in italics):

- Provision of in-depth, clear and concise explanations of key concepts ("[the videos] explained key lecture concepts in depth so you had an understanding before lectures"; "Expanded on content, providing more explanation and detail to enhance understanding");

- Use of visual representation of information, through diagrams and illustrations, that, at times, consolidated and revised learning ("[The videos] often have

Table 5 A summary of the ways in which the flipped videos were most helpful to students' learning

\begin{tabular}{lc}
\hline Themes & Frequency \\
\hline Provided requisite knowledge for lectures and/or tutorials & 62 \\
Clear and concise explanations of key concepts/content & 39 \\
Supported understanding of key concepts & 28 \\
Visual representation of information & 12 \\
In-depth explanations of key concepts & 12 \\
Introduced new topics/key concepts & 11 \\
To consolidate and revise learning & 10 \\
Ability to pause and replay videos & 10 \\
Fostered deep learning & 6 \\
Auditory representation of information & 4 \\
An additional resource for learning & 3 \\
The videos were enjoyable/engaging & 2 \\
Provision of notes to accompany the videos & 2 \\
\hline
\end{tabular}


diagrams/pictures (visual cues) that helped me to understand the topic"; "The picture of the CFC [chlorofluorocarbon molecule] and the explanation helped me understand greatly, then I watched a YouTube video, by the end I fully understood ozone depletion. I always watched them after I did the readings to fully grapple with the content"); and

- The ability to pause and replay the videos, so that learning could occur at their own pace ("I was also able to stop and replay the parts that were hard to understand. After the lecture I could also play them again to check if I understood").

One of the two respondents who indicated that the videos were not helpful for their learning felt that the "content was delivered well enough in lectures and tutorials".

\section{Students' perceptions of the flipped learning approach}

Key finding 4: while, for a majority of students, the flipped approach enhanced their motivation to learn, opinions were divided as to whether it was a preferred or more engaging approach than traditional lectures

It was encouraging to find that most respondents agreed that the flipped learning approach enhanced their motivation to learn the subject content; however, nearly a third neither agreed nor disagreed, or did not believe that the approach motivated them to learn (Table 6). Similarly, students' views on the flipped learning approach compared to traditional lecture instruction were also variable. While half reported that the approach was more engaging that traditional lectures, a third of respondents were neutral, and nearly $15 \%$ did not agree that flipped learning was more engaging. When asked to nominate their preference for a flipped classroom over traditional lectures, more than half of respondents were either undecided, or reported that they did not prefer a flipped classroom in place of regular lectures.

In spite of the variability in students' perceptions, the majority appeared to respond positively to the flipped classroom approach. Approximately three-quarters

Table 6 Students' views on the flipped learning approach employed in FSE $(n=171)$

\begin{tabular}{|c|c|c|c|c|c|c|}
\hline \multirow[t]{3}{*}{ Item } & \multicolumn{5}{|c|}{ Responses, n (\%) } & \multirow[t]{3}{*}{ Mean } \\
\hline & $\begin{array}{l}\text { Strongly } \\
\text { agree }\end{array}$ & Agree & $\begin{array}{l}\text { Neither agree } \\
\text { nor disagree }\end{array}$ & Disagree & $\begin{array}{l}\text { Strongly } \\
\text { disagree }\end{array}$ & \\
\hline & 1 & 2 & 3 & 4 & 5 & \\
\hline $\begin{array}{l}\text { The flipped classroom approach } \\
\text { made me feel more motivated } \\
\text { to learn the content within the } \\
\text { modules }\end{array}$ & 46 (26.9) & $73(42.7)$ & $43(25.1)$ & $9(5.3)$ & 0 & 2.09 \\
\hline $\begin{array}{l}\text { I found the flipped classroom } \\
\text { more engaging than traditional } \\
\text { lecture instruction* }\end{array}$ & $31(18.2)$ & 57 (33.5) & $57(33.5)$ & $23(13.5)$ & $2(1.2)$ & 2.46 \\
\hline $\begin{array}{l}\text { I would not recommend the } \\
\text { flipped classroom approach** }\end{array}$ & $6(3.6)$ & $12(7.1)$ & $27(16.0)$ & $74(43.8)$ & $50(29.6)$ & 3.89 \\
\hline $\begin{array}{l}\text { I would rather a traditional } \\
\text { lecture approach than the } \\
\text { flipped classroom approach* }\end{array}$ & $5(2.9)$ & 18 (10.6) & $68(40.0)$ & $51(30.0)$ & $28(16.5)$ & 3.46 \\
\hline
\end{tabular}

Notes: The mode for each item is bolded. ${ }^{*} n=170$ for these items. ${ }^{* *} n=169$ for this item 
of participants $(n=124)$ disagreed with the statement, "I would not recommend the flipped classroom approach" (Table 6).

\section{Educators' perspectives on enacting the active learning strategies}

Key finding 5: additional teacher-led instruction, scaffolding and guidance were required inclass to review the concepts explored in the flipped videos, and to support students to complete the active learning tasks successfully

In the following section, we offer a narrative account of Louisa and Snowy's experiences enacting the active learning strategies during class that emerged from the reflective analysis of their teaching observations and reflections. We also outline the implications for the flipped learning approach in FSE.

\section{Our story: charting new ground}

At the commencement of our flipped learning project, we planned to develop and record a suite of flipped videos, remove the corresponding content from the lectures, and develop and deliver a range of student-centred activities that enabled our students to apply their knowledge in different ways in class. For the most part, we were able to execute our plan as intended; however, it became clear early in the semester that students were not engaging with the active learning strategies as we expected.

At the start of the first 'flipped lecture', we began by asking questions to review the content of the video to check for understanding, before introducing the forthcoming activity; a mind map that illustrates the key ideas associated with current trends in human population growth. Students appeared reluctant to answer our questions and engage in a whole-class discussion. We wondered whether this was because students were shy, or because they did not watch the videos before class; however, most reported that they did by a show of hands, when asked. Perhaps they could not answer our questions because they did not understand the material after reviewing the videos on their own. When we attempted to move onto the human population mind map activity, we were met with variable levels of student engagement. After introducing and scaffolding the task, we found that some students commenced their mind maps with relative confidence, while others appeared to struggle. Sitting with these groups of students, we reviewed the underpinning key concepts, asked additional questions, and offered further scaffolding (such as modelling what was required), until they were able to work on their mind maps independently. While everyone had managed to successfully produce a mind map at the close of the activity, the quality of work was variable: some mind maps were detailed, with many concepts and accurate connections between them, while others, not so.

In the second flipped week, wherein students learned about the physical and chemical properties of water, and how these are related to its molecular structure, we encountered a similar level of reluctance to engage in a discussion about the key concepts in the flipped videos; however, we encountered greater resistance as they commenced the planned activity, compared to the week prior. This week, the two flipped videos focused on hydrogen bonding. The in-class activity required students to write a summary of the concepts explored on the A3 paper provided, that incorporated 10 given key terms, such as 
'compound,' 'hydrogen bonding,' covalent bond' and 'polar molecule'. While presented as a 'summary' task, it called for a clear understanding of the key terms and how they related to each other (much like the mind map activity). Compared to human population growth, this content appeared more demanding for students to understand, and they were required to use specific (and perhaps new) science terminology in context. Just like the week before, significant teacher-led instruction was required before students could engage with the activity; however, we noticed that this week called for more intensive review with the whole class. At the end of the activity, students were asked to identify any key concepts that they were still unsure about, by putting forward one question per small group on a 'sticky note'. Overall, students were still uncertain about hydrogen bonding, even after having viewed the flipped videos and completing the in-class activity. This exercise yielded five main questions related to hydrogen bonding (e.g., "What is a polar molecule?") that called for further teacher-led instruction in the week that followed.

As the semester progressed, we encountered variable levels of engagement with the planned activities. Like the water chemistry week, those with a strong focus on abstract science concepts, such as ozone depletion and the greenhouse effect, appeared to hinder students' engagement the most. We came to expect that we could not move immediately to the active learning strategies during the flipped weeks. Instead, we explicitly reviewed the concepts examined in the videos in-depth through teacher-led instruction, which involved further verbal explanations of the content, drawing diagrams, watching parts of the videos in class, and questioning. Additional guidance and scaffolding were also required to support students to complete the activities successfully, as their knowledge was tested in unfamiliar contexts. It felt as though we had tried to take students' 'training wheels' off too early, before they had learned to ride the bike.

\section{Epilogue}

The narrative account of Louisa and Snowy's experiences enacting the active learning strategies for the first time in FSE illustrates some interesting observations about how students engaged with the planned activities, which called for them to adjust their teaching in a way that was somewhat unexpected. In this way, Louisa and Snowy were 'charting new ground' on their pedagogic journeys. As the semester unfolded, the flipped learning approach was refined, such that some of the instructional decisions that were made 'in the moment' were anticipated and carefully planned. It came to be that the model of flipped learning evolved, such that it adopted the following approach:

1. Students engaged with the flipped videos (which supplemented the online modules and readings) prior to attending class;

2. The concepts in the flipped videos were reviewed in-depth using teacher-led instruction and questioning at the start of class; and.

3. After checking for understanding, students progressed to the planned activities, with guidance and support.

This approach, which drew on aspects of both a flipped classroom and traditional lectures, in response to students' needs, led us to consider the notion of a 'flipped 
learning continuum'. In the section below, we discuss the findings of our study in greater detail, and present our conceptualisation of a flipped learning continuum.

\section{Summary and discussion}

In this paper, we explored how a flipped learning approach supported pre-service teachers' engagement and learning in a first year science and sustainability education subject. In response to Research Question 1, the survey revealed high levels of student engagement with the flipped videos (Key Finding 1). Students generally viewed each video twice, and while most watched them before the lectures as intended, nearly $40 \%$ watched them after lectures, too. When asked to identify why they did not watch some of the flipped videos, the two most frequently cited factors here were a lack of time, particularly around other study commitments, and simply forgetting to watch them (Key Finding 2). Aside from determining whether students watched the videos at all, the availability of time also determined when they watched them (e.g., before or after lectures). This is a significant finding, because it highlights the importance of supporting students in the first year experience. How well students manage their study commitments during their first year of university depends on a range of factors, including: their attitudes towards study; personal skills such as time management and self-organisation; other commitments such as paid work and family responsibilities; and the demands of their course (Krause, Hartley, James, \& McInnis, 2005). As university students navigate a flipped classroom, very clear expectations must be conveyed to encourage them to take responsibility for their own learning outside of class time (O’Flaherty \& Phillips, 2015). Introducing a weekly quiz can also be an effective strategy for motivating students to complete the required work before class (Bishop \& Verleger, 2013).

In response to the second research question, nearly all survey respondents (98.8\%) believed that the flipped videos supported their learning by providing clear and concise explanations of key concepts that helped them to prepare for or better understand the lectures (Key Finding 3). This likely explains why most students chose to watch them. While this finding is useful in terms of understanding how a flipped classroom might support student learning, we did not measure any changes in students' conceptual understanding. Such remains an important line of inquiry in future investigations.

The final survey question revealed some interesting findings regarding students' perceptions of the flipped learning approach (Research question 3). Respondents' opinions regarding whether a flipped classroom motivated them to learn, or was more engaging than traditional instruction, were divided (Key Finding 4). While we did not elicit student feedback regarding their experiences of the flipped lectures (a limitation of the current study, and one that could be explored in future through student focus groups), it could be the case that the cognitive demand associated with learning new science and sustainability concepts before class, and applying their knowledge in class, was not particularly motivating. First year students may also resist the requirement to take control of their learning due to their previous secondary school experiences, which may have shaped their learning expectations and their perceptions of the teacher's role (Baird \& Mitchell, 1987).

Students' divided opinions about traditional lectures and flipped classrooms also speaks strongly of their expectations of university study. In her exploration of 
Australian engineering undergraduates' attitudes towards blended learning, Jefferies (2015) found that not all students are willing to engage in online course components, particularly school-leavers who specifically elect to study on-campus to engage personally with experienced educators. In short, she observed an "... unwillingness to change from a familiar teacher-led pedagogic style” (p. 1105). Similarly, the introduction of a flipped classroom calls for very clear expectations to be conveyed to students, who may depend on a traditional lecture approach "... because it is familiar, comfortable, instructor centred and requires little active participation" (O'Flaherty \& Phillips, 2015, p. 89).

In articulating a 'transition pedagogy', Kift (2009) maintains that the first year curriculum should support students' successful transition into higher education. While active and collaborative learning is important (Kift, 2009), the survey findings suggest that disrupting students' expectations of university study may be met with some resistance, and call for a blended approach that incorporates both teacher-led and student-centred pedagogies, as reflected in the current study.

\section{Reflecting on practice: a flipped learning continuum}

Our reflections on Louisa and Snowy's experience of enacting the active learning strategies offered some telling insights into how students engaged with them (Research Question 4). Students appeared reluctant to engage with the planned activities, which required further teacher-led instruction, questioning and scaffolding (Key Finding 5). This additional instruction seemed to be appreciated by students. As one student noted in the survey, "I liked how in some lectures the videos were referred to [to] help learning". After reviewing key concepts in-depth, students progressed to the activities, albeit with greater scaffolding, guidance and support than anticipated.

Although Louisa and Snowy wondered whether students had watched the flipped videos before class, the survey revealed that, for the most part, they did. They also wondered whether students did not understand the concepts enough to be able to participate actively in class; however, the survey also showed that most students believed that the videos helped them to prepare by supporting their understanding of key concepts. While this represents an interesting contradiction between students' perceptions of the usefulness of flipped videos and the educators' experiences enacting the active learning strategies, students' ambivalence towards the flipped learning approach (as per the final survey question) is perhaps more confirmatory of Louisa and Snowy's observations of their engagement in class. Although students' learning was not measured in this study, it is possible that students' actual understanding was not sufficient for them to engage independently with the activities. It is also possible that students were resistant to playing an active role in their own learning during class time (cf. Baird \& Mitchell, 1987; Jefferies, 2015). As Louisa and Snowy reflected, it felt as though they had taken off students' 'training wheels' before they had learned to ride the bike. In other words, were the first year students ready for a flipped learning approach?

In this case study, it appears that coupling the flipped videos with teacher-led instruction in class, worked best to support students' engagement with the active learning strategies. This finding is significant, and seeded the idea that a 'flipped learning continuum' may be required when students' learning needs call for different levels of 


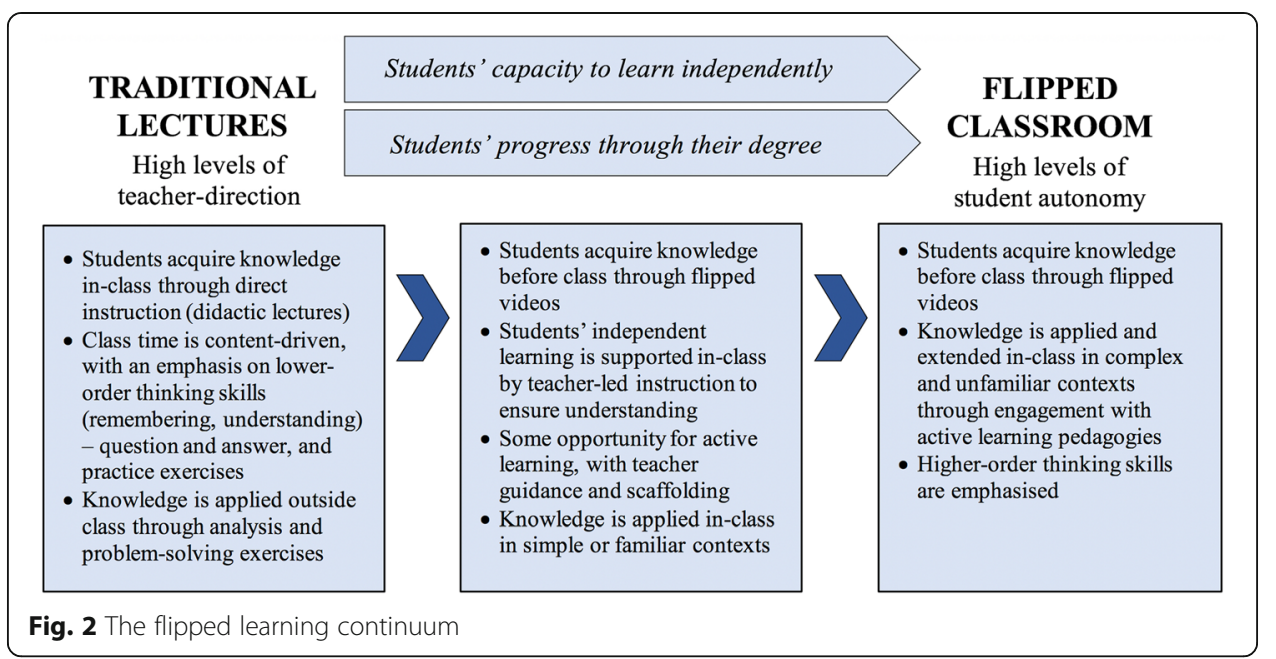

teacher-led instruction and scaffolding, and of student autonomy, knowledge application and extension. In Fig. 2, we offer our interpretation of a flipped learning continuum. Traditional instruction is positioned on the left-hand side, wherein lectures are content-driven, with a focus on knowledge acquisition and lower-order thinking skills (Zainuddin \& Halili, 2016). Opportunities to apply and extend knowledge come by way of problem-solving exercises that are set for homework. On the right-hand side of the continuum is the flipped classroom, which draws on attributes described by Bishop and Verleger (2013), MacKinnon (2015), and Zainuddin and Halili (2016), and is characterised by high levels of student autonomy and higher order thinking.

In the middle of the continuum, there are learning environments that draw on aspects of both traditional and flipped learning approaches. This is where we situate teaching and learning in FSE. Opportunities for students to acquire new knowledge before class are complemented by teacher-led instruction during lectures. Studentcentred activities are supported and scaffolded by the teacher, as is appropriate in the first year experience (Kift, 2009). Conceptually demanding subjects, like FSE, may also necessitate some teacher-led instruction.

At the top of the continuum are two arrows. These arrows suggest that a move from traditional lectures to a flipped classroom might occur gradually over time, depending on students' capacity to learn independently, and their progress through their degree. These arrows suggest that students are less likely to have the skills, knowledge and capacity to learn though an entirely flipped approach early on in their degree - as could be inferred by our experience in FSE. In the context of a pre-service teacher education program, for example, higher levels of autonomy and self-direction could be afforded to third- and fourth-year students who are more likely to have acquired the necessary skills (and motivation) to learn independently and engage successfully in an entirely flipped approach. In a recent study by Howitt and Pegrum (2015), for example, a successful transition to student-centred learning occurred during their implementation of a flipped approach; however, the authors note that postgraduate Education students "are often more motivated and committed than undergraduate students" (p. 468).

While reflections about students' readiness for a flipped learning approach was a somewhat unexpected outcome of this study, this problem was investigated in a recent 
study by Hao (2016). Eighty-four undergraduate Education students in Taiwan were surveyed after a semester of flipped learning to investigate their perceptions of a flipped classroom, and their flipped learning readiness. While approximately $60 \%$ of respondents agreed with the student-centred notion of a flipped classroom, less than $40 \%$ agreed that a flipped approach met their learning needs; $40 \%$ were neutral; and half indicated that they would not choose to take another flipped class. It was also found that first year students demonstrated lower levels of flipped learning readiness than those in their third year of study. In their responses to open-ended survey questions, these students expressed "a lack of disposition for active learning ... and admitted they were not used to taking control of their own learning" (p. 90). Hao concludes that students may require a gradual introduction to flipped learning over time, as well as explicit support to develop particular attributes (such as self-directed learning skills) to enhance their readiness for the student-centred nature of flipped classrooms.

Interestingly, the idea of including some teacher-led instruction in a modified flipped classroom is not new. In Bishop and Verleger's (2013) survey of flipped learning research, they review a study by Moravec and colleagues (2010), wherein students in an introductory biology course participated in alternating ten-minute mini-lectures and five- to seven-minute active learning exercises. The authors note that the "... in-class activities still carried a lecture component, even though time was provided for interactive activities" (p. 10); an approach they term a 'partial flip' (p. 11). While this approach led to a $21 \%$ improvement in student performance on the related examination questions, Bishop and Verleger (2013) argue that the inclusion of a lecture component represented a 'short coming' of the study. We would argue, however, that some teacher-led instruction might be necessary, depending on students' learning needs, and their readiness for a flipped learning approach. Hao (2016) concurs with this position, asserting that "... it is essential for instructors to evaluate student readiness levels to flip their classrooms [and] to be adaptive and tailor their flipped classrooms to meet the needs of individual students" (p. 91).

\section{Concluding remarks}

The flipped learning continuum proposed in this article offers a new direction in the discussion on best practice for flipping the classroom in ways that best support students' engagement and learning. In the first year experience, the delivery of the curriculum should support "... students' transition from their previous educational experience to the nature of learning in higher education and learning in their discipline" (Kift, 2009, p. 40, original emphases). As secondary school education is often dominated by the transmission model of teaching (see, for example, Goodrum, Druhan, \& Abbs, 2012), we suggest that measures to adapt the flipped classroom to mediate this transition are warranted. Importantly, given that “... it is difficult to identify when, under what circumstances and in what ways the flipped classroom approach might be relevant as a pedagogical choice" (Lundin et al., 2018), the findings of this study begin to shed some light on important pedagogical considerations when seeking to engage first year students in flipped learning.

While this study was conducted in a pre-service teacher education context, its findings offer great utility in informing the development of effective blended learning 
approaches in higher education, more broadly. Further research, including empirical studies, is required to investigate the applicability of the flipped learning continuum in a range of learning contexts, with a view to understand better how learning outcomes can be effectively facilitated.

\section{Endnotes}

${ }^{1}$ This colleague, who was subsequently invited to be a co-author, was involved over an extended period as an external reviewer associated with a 'Peer Review of Teaching' initiative related to the flipped learning intervention that is the focus of this paper. $\mathrm{He}$ became involved as an external reviewer after the implementation of the intervention (and the collection of associated data) and his peer validation comments were sought after interpretations of the data were completed.

\section{Appendix}

Peer validation statement (K. Skamp, personal communication, July 24, 2018)

"The following comments are from a teacher educator who has researched and taught science and sustainability education in undergraduate teacher education degrees (for primary teachers) for many years.

These teacher educators' reflections, on their use of a flipped learning approach, with first year undergraduate students, resonates with my teaching experiences with first year (teacher education) students. When I have set tasks, to be completed before attending tutorials, often students addressed them in a superficial manner, with the expectation that they would be 'spoon-fed' when they came to the tutorials. In some respects, this was probably due to (some) other (concurrent) lecturers not expecting students to take on some responsibility for their own learning; hence, students experienced conflicting expectations across lecturers (in different units/ courses); this aspect could be explored in further iterations in the use of flipped videos.

Also, with such tasks (i.e., set before tutorials, and hence analogous in some ways with the use of flipped videos) it was almost inevitable that additional scaffolding was required before other tutorial objectives (from the lecturer's perspective) could be addressed. What these teacher educators describe related to their students' responses to the 'active learning' tasks (in class [i.e., the first hour of the lecture]), therefore, is very similar to what I have experienced with first year teacher education students (especially when the subject content was 'science' related). The account is 'highly plausible' especially for the subject matter that is the focus and for the background and previous science experiences of the cohorts.

Furthermore, the interpretation of the encounters these teacher educators had with their students when they asked them to engage in 'active learning' tasks, often with a metacognitive component (in the 'class' [after the students had been asked to interact with the flipped videos]), made sense and was insightful. It drew upon relevant literature that supported their reflections: from both general education literature regarding student learning at universities as well as the science education research literature. I was able to 'identify' with the proffered interpretations. What these teacher educators could consider is asking their students how they are learning (and hence help then to realise what it means to be 'metacognitive' [as they learn]). 
Not only were the interpretations similar to conclusions I would have drawn from the data, but the flipped learning continuum will provide teacher educators (and university lecturers in general) 'food for thought' about what might eventuate if they decide to use flipped videos (and hence a flipped learning approach) in their units/courses. If they experience difficulties, then the conclusions from the 'narrative' (and the linked survey findings) could prove to be 'most useful' as they would then be able to identify with these teacher educators' experiences and explore their suggestions for ways forward".

Acknowledgements

Not applicable.

Funding

This research was funded by a James Cook University Teaching and Learning Development Grant (\$10 000).

Availability of data and materials

Please contact the corresponding author.

Authors' contributions

LT was involved in all aspects of this research, including data collection, data analysis and writing of the manuscript. SE was involved in data collection and analysis, and writing of the manuscript. TD was involved in data collection and writing of the manuscript. KS served as an external reviewer associated with a 'Peer Review of Teaching' initiative related to the flipped learning intervention that is the focus of this paper, and externally validated the narrative presented herein. KS was a major contributor in refining and editing the manuscript, and sourcing literature. All authors read, edited and approved the final manuscript.

\section{Competing interests}

The authors declare that they have no competing interests.

\section{Publisher's Note}

Springer Nature remains neutral with regard to jurisdictional claims in published maps and institutional affiliations.

\section{Author details}

'College of Arts, Society \& Education, James Cook University, 1 James Cook University Drive, Townsville, QLD 4811, Australia. ${ }^{2}$ College of Arts, Society \& Education, James Cook University, 14-88 McGregor Road, Smithfield, QLD 4878, Australia. ${ }^{3}$ School of Education, Southern Cross University, Military Road, Lismore, NSW 2480, Australia.

Received: 15 August 2018 Accepted: 7 February 2019

Published online: 01 March 2019

\section{References}

Australian Education for Sustainability Alliance. (2014). Education for sustainability and the Australian curriculum project, final report for research phases 1-3. Retrieved from: http://www.educationforsustainability.org.au/publications/final-report-forphases-1-3-education-for-sustainability-and-the-australian-curriculum-project/. Accessed 28 May 2018.

Baepler, P., Walker, J. D., \& Driessen, M. (2014). It's not about seat time: Blending, flipping, and efficiency in active learning classrooms. Computers \& Education, 78, 227-236. https://doi.org/10.1016/j.compedu.2014.06.006.

Baird, J. R., \& Mitchell, I. J. (1987). Improving the quality of teaching and learning: An Australian case study, the PEEL project. Melbourne: Monash University Press.

Bishop, J. L., \& Verleger, M. A. (2013). The flipped classroom: A survey of the research. In ASEE National Conference Proceedings, Atlanta, GA (Vol. 30, No. 9, pp. 1-18).

Bonwell, C. C., \& Eison, J. A. (1991). Active Learning: Creating Excitement in the Classroom. ASHE-ERIC Higher Education Report No. 1. Washington D.C.: The George Washington University, School of Education and Human Development.

Campbell, M. (2007). Why the silence on populations? Population and Environment, 28(4-5), 237-246.

Chen, Y., Wang, Y., Kinshuk, \& Chen, N.-S. (2014). Is FLIP enough? Or should we use the FLIPPED model instead? Computers \& Education, 79, 16-27. https://doi.org/10.1016/j.compedu.2014.07.004.

Cheng, Y., \& Weng, C. (2017). Factors influence the digital media teaching of primary school teachers in a flipped class: A Taiwan case study. South African Journal of Education, 37(1), 1-12. https://doi.org/10.15700/saje.v37n1a1293.

Clandinin, D. J., \& Connelly, F. M. (2000). Narrative inquiry: Experience and story in qualitative research. San Francisco: Jossey Bass.

Connelly, F. M., \& Clandinin, D. J. (1990). Stories of experience and narrative inquiry. Educational Researcher, 19(5), 2-14. https://doi.org/10.3102/0013189X019005002.

Cortese, A. D. (2003). The critical role of higher education in creating a sustainable future. Planning for Higher Education, 31(3), 15-22.

Cotton, D., \& Winter, J. (2010). It's not just bits of paper and light bulbs': A review of sustainability pedagogies and their potential for use in higher education. In P. Jones, D. Selby, \& S. Sterling (Eds.), Sustainability education: Perspectives and practice across higher education, (pp. 39-54). London: Earthscan.

Crosling, G., Heagney, M., \& Thomas, L. (2009). Improving student retention in higher education: Improving teaching and learning. Australian Universities' Review, 51(2), 9-18. 
Dziuban, C., Graham, C. R., Moskal, P. D., Norberg, A., \& Sicilia, N. (2018). Blended learning: The new normal and emerging technologies. International Journal of Educational Technology in Higher Education, 15(1), 1-16. https://doi.org/10.1186/ s41239-017-0087-5.

Evans, N., Tomas, L., \& Woods, C. (2016). Impact of sustainability pedagogies on pre-service teachers' self-efficacy. Journal of Education for Sustainable Development, 10(2), 1-19. https://doi.org/10.1177/0973408216650953.

Fulton, K. (2012). Upside down and inside out: Flip your classroom to improve student learning. Learning \& Leading with Technology, 39(8), 12-17.

Gall, M. D., Borg, W. R., \& Gall, J. P. (2007). Educational research: An introduction, (8th ed., ). Boston: Pearson.

Glazer, F. S. (2012). Introduction. In F. S. Glazer (Ed.), Blended Learning: Across the disciplines, across the academy, (pp. 1-12). Sterling: Virginia: Stylus Publishing, LLC.

Goodrum, D., Druhan, A., \& Abbs, J. (2012). The Status and Quality of Year 11 and 12 Science in Australian Schools. Canberra: Australian Academy of Science.

Hao, Y. (2016). Exploring undergraduates' perspectives and flipped learning readiness in their flipped classrooms. Computers in Human Behavior, 59, 82-92. https://doi.org/10.1016/j.chb.2016.01.032.

Herreid, C. F., \& Schiller, N. A. (2013). Case studies and the flipped classroom. Journal of College Science Teaching, 42(5), 62-66.

Howitt, C., \& Pegrum, M. (2015). Implementing a flipped classroom approach in postgraduate education: An unexpected journey into pedagogical redesign. Australasian Journal of Educational Technology, 31(4), 458-469.

Huereca, K. (2015). High school mathematics teachers' connective knowledge of the challenges and possibilities in implementing the flipped learning model: An embedded mixed-methods study. Published dissertation: The University of Texas at El Paso.

James Cook University. (2014). Blended learning policy. Retrieved from http://www.jcu.edu.au/policy/allatoh/JCU_140716.html.

Jefferies, A. (2015). Are our students digitally ready for HE study? Exploring student attitudes to blended online study in a campus-based university. American Journal of Educational Research, 3(9), 1098-1106.

Jensen, J. L., Holt, E. A., Sowards, J. B., Ogden, T. H., \& West, R. E. (2018). Investigating strategies for pre-class content learning in a flipped classroom. Journal of Science Education and Technology, 27(6), 523-535. https://doi.org/10.1007/s10956-018-9740-6.

Jeong, J. S., González-Gómez, D., \& Cañada-Cañada, F. (2016). Students' perceptions and emotions toward learning in a flipped general science classroom. Journal of Science Education and Technology, 25(5), 747-758. https://doi. org/10.1007/s10956-016-9630-8.

Keppell, M., \& Riddle, M. (2011). Distributed learning places: Physical, blended and virtual learning spaces in higher education. In Physical and Virtual Learning Spaces in Higher Education: Concepts for the Modern Learning Environment, (pp. 1-20). Hershey: IGI Publishing (IGI Global).

Kift, S. (2009). Articulating a transition pedagogy to scaffold and to enhance the first year student learning experience in Australian higher education: Final report for ALTC senior fellowship program. Strawberry Hills: Australian Learning and Teaching Council.

Krause, K. L., Hartley, R., James, R., \& McInnis, C. (2005). The first year experience in Australian universities: Findings from a decade of national studies. In Australian Government Department of Education, Science and Training.

Lasen, M., Tomas, L., Whitehouse, H. Sorin, R., Evans, S., \& Stevenson, R. (2015). A case study of an Australian university embedding EfS in a pre-service teaching program. In S. Stratton, R., Hagevik, A. Feldman \& M. Bloom (Eds.), Educating Science Teachers for Sustainability. New York: Springer.

Loh, J. (2013). Inquiry into issues of trustworthiness and quality in narrative studies: A perspective. The Qualitative Report, 18(33), 1-15.

Love, B., Hodge, A., Grandgenett, N., \& Swift, A. W. (2014). Student learning and perceptions in a flipped linear algebra course. International Journal of Mathematical Education in Science and Technology, 45(3), 317-324. https://doi.org/10.1080/ 0020739X.2013.822582.

Lundin, M., Rensfeldt, A. B., Hillman, T., Lantz-Andersson, A., \& Peterson, L. (2018). Higher education dominance and siloed knowledge: A systematic review of flipped classroom research. International Journal of Educational Technology in Higher Education, 15(1), 1-30. https://doi.org/10.1186/s41239-018-0101-6.

MacKinnon, G. (2015). Determining useful tools for the flipped science education classroom. Contemporary Issues in Technology and Teacher Education, 15(1), 44-55.

McCarthy, J. (2016). Reflections on a flipped classroom in first year higher education. Issues in Educational Research, 26(2), 332-350

Milman, N. B. (2012). The flipped classroom strategy: What is it and how can it best be used? Distance Learning, 9(3), 85-87.

Misseyanni, A., Lytras, M. D., Papadopoulou, P., \& Marouli, C. (2018). Introduction. In A. Misseyanni, M. D. Lytras, P. Papadopoulou, \& C. Marouli (Eds.), Active Learning Strategies in Higher Education: Teaching for Leadership, Innovation, and Creativity, (pp. 1-13). United Kingdom: Emerald Publishing Limited.

Moravec, M., Williams, A., Aguilar-Roca, N., \& O'Dowd, D. K. (2010). Learn before lecture: A strategy that improves learning outcomes in a large introductory biology class. CBE - Life Sciences Education, 9(4), 473-481.

Morse, J. M. (2003). Principles of mixed methods and multimethod research design. In A. Tashakkori, \& C. Teddlie (Eds.), Handbook of mixed methods in social and behavioral research, (pp. 189-208). Thousand Oaks: Sage Publications.

Morse, P. (2000). Education and understanding science and the earth system for long-term sustainability. In K. Wheeler, \& A. Perraca Bijur (Eds.), Education for a sustainable future: A paradigm of hope for the 21st century, (pp. 113-122). New York: Kluwer Academic.

Nichols, K., Burgh, G., \& Kennedy, C. (2017). Comparing two inquiry professional development interventions in science on primary students' questioning and other inquiry behaviours. Research in Science Education, 47(1), 1-24. https://doi.org/10. 1007/s11165-015-9487-5.

Nouri, J. (2016). The flipped classroom: For active, effective and increased learning-especially for low achievers. International Journal of Educational Technology in Higher Education, 13(1), 1-10. https://doi.org/10.1186/s41239016-0032-z.

Nulty, D. D. (2008). The adequacy of response rates to online and paper surveys: What can be done? Assessment \& Evaluation in Higher Education, 33(3), 301-314. https://doi.org/10.1080/02602930701293231.

O'Flaherty, J., \& Phillips, C. (2015). The use of flipped classrooms in higher education: A scoping review. Internet and Higher Education, 25, 85-95. https://doi.org/10.1016/j.iheduc.2015.02.002. 
Osguthorpe, T. R., \& Graham, R. C. (2003). Blended learning environments. Quarterly Review of Distance Education, $4(3), 227-233$.

Roehl, A., Reddy, S. H., \& Shannon, G. J. (2013). The flipped classroom: An opportunity to engage millennial students through active learning strategies. Journal of Family and Consumer Sciences, 105(2), 44-49.

Roth, K. (2014). Elementary science teaching. In N. Lederman, \& S. Abell (Eds.), Handbook of research on science education, (vol. 2, pp. 361-394). New York: Routledge.

Saldaña, J. (2013). The coding manual for qualitative researchers, (2nd ed., ). Thousand Oaks: Sage.

Singh, T. (2010). Creating opportunities for students in large cohorts to reflect in and on practice: Lessons learnt from a formative evaluation of students' experiences of a technology-enhanced blended learning design. British Journal of Educational Technology, 41(2), 271-286. https://doi.org/10.1111/j.1467-8535.2009.00933.x.

Stevenson, R. B., Brody, M., Dillon, J., \& Wals, A. E. J. (2013). International Handbook of Research on Environmental Education. New York: Routledge, New York.

Tomas, L., Lasen, M., Field, E., Skamp, K. (2015). Promoting online students' engagement and learning in science and sustainability preservice teacher education. Australian Journal of Teacher Education, 40(11), 78-107. https://doi.org/10. 14221/ajte.2015v40n11.5.

Vaughan, M. (2014). Flipping the learning: An investigation into the use of the flipped classroom model in an introductory teaching course. Education Research and Perspectives (Online), 41, 25.

Wals, A. E., \& Jickling, B. (2002). "Sustainability" in higher education: From doublethink and newspeak to critical thinking and meaningful learning. International Journal of Sustainability in Higher Education, 3(3), 221-232. https://doi.org/10.1108/ 14676370210434688.

Wals, A. E. J., Brody, M., Dillon, J., \& Stevenson, R. B. (2014). Convergence between science and environmental education Science, 344(6184), 583-584. https://doi.org/10.1126/science.1250515.

Warburton, K. (2003). Deep learning and education for sustainability. International Journal of Sustainability in Higher Education, 4(1), 44-56. https://doi.org/10.1108/14676370310455332.

Yin, R. K. (2018). Case Study Research: Design and Methods, (6th ed., ). California: Sage Publications.

Zainuddin, Z., \& Halili, S. H. (2016). Flipped classroom research and trends from different fields of study. International Review of Research in Open and Distributed Learning, 17(3). https://doi.org/10.19173/irrodl.v17i3.2274.

\section{Submit your manuscript to a SpringerOpen ${ }^{\circ}$ journal and benefit from:}

- Convenient online submission

- Rigorous peer review

- Open access: articles freely available online

High visibility within the field

- Retaining the copyright to your article

Submit your next manuscript at $\boldsymbol{\nabla}$ springeropen.com 